DOI https://doi.org/10.30525/978-9934-26-182-4-48

\title{
РОЛЬ ВИВЧЕННЯ НЕМЕДИКАМЕНТОЗНИХ МЕТОДІВ ЛІКУВАННЯ У ПРОФІЛАКТИЦІ СЕРЦЕВО-СУДИННИХ ЗАХВОРЮВАНЬ
}

\author{
Лукашенко Л. В. \\ доктор медичних наук, професор, \\ професор кафедри пропедевтики внутрішньої медицини, \\ променевої діагностики та променевої терапії \\ Запорізький державний медичний університет
}

Лихасенко I. B.

кандидат медичних наук, доцент,

доцент кафедри пропедевтики внутрішньої медицини, променевої

діагностики та променевої терапії

Запорізький державний медичний університет

м. Запоріжжя, Украӥна

Важливим елементом в терапевтичній практиці сьогодення відводиться профілактиці і немедикаментозним методам лікування хворих 3 серцево-судинними захворюваннями (СС3). Зменшити темпи поширення хвороб серця можна, проте для цього необхідно мінімізувати основні фактори ризику ССЗ: високий артеріальний тиск, незбалансоване харчування, підвищений рівень ліпопротеїдів низької щільності, паління, цукровий діабет, малорухливий спосіб життя, зловживання алкоголем та стреси [1, с. 1]. Результати проведеного у 2019 році дослідження STEPS свідчать, що 32,8\% населення України мають 3-5 факторів ризику розвитку СС3, а 60,1\% - 1-2 фактори ризику. Водночас кількість факторів ризику зростала з віком [1, с. 62]. Корекція навіть одного з факторів ризику $\mathrm{CC} 3$, робить такий же потужний вплив на прогноз, як і застосування стандартних кардіопротекторних режимів.

Одним з основних методів поліпшення прогнозу пацієнтів $є$ відмова від паління [2, с. 3273]. Паління розглядається як один із найбільш вагомих факторів серцево-судинного ризику. Також воно асоційоване і з високим ризиком розвитку бронхо-легеневих захворювань, онкологічних процесів різного роду та ін. Ступінь серцево-судинного ризику чітко пов'язана 3 кількістю сигарет, що викурюються. Для інфаркту міокарда це пряма залежність. Так, при викурюванні 5-6 сигарет на добу ризик інфаркту міокарда у курця порівняно з некурцем збільшений приблизно в 2 рази, 
при викурюванні 1 пачки - у 5-6 разів. Згідно з результатами дослідження INTERHEART, наявність фільтра, і навіть використання «легких» («light») тютюнових виробів значимо не впливає на зазначений рівень підвищення ризику ССЗ. Інші форми вживання тютюну (кальян, сигари, а також некурильні - маловикористовувані у нас - нюхання і жування) показують такий самий високий рівень негативного впливу на серцево-судинний ризик. Важливо зазначити, що ризик при пасивному курінні («second-hand smoking») наближається до такого при активному палінні.

Відмова від куріння призводить до значного сприятливого серцевосудинного ефекту [2, с. 3273]. Показано, що у хворих 3 хронічною ішемічною хворобою серця (IXC) при зниженій систолічній функції лівого шлуночку (ЛШ) припинення куріння забезпечує таке само виражене зниження смертності (на $30 \%$ ), як і лікування $\beta$-адреноблокаторами (на $34 \%$ ) та більш значне - ніж лікування інгібіторами АПФ (на 19\%). Вважають, що при стійкій відмові від куріння (не менше 2 років) рівень серцево-судинного ризику у осіб, які кинули палити, знижується приблизно до рівня некурців ( відповідної вікової та статевої групи), хоча невеликий ступінь резидуального ризику зберігається тривало.

Не менш важливим фактором кардіального ризику є зловживання кухонною сіллю, тому пояснення пацієнтові необхідності обмеження іiі вживанняє дуже важливим [1, c. 16]. Доведеним фактом є прямий зв'язок між надлишком кухонної солі в раціоні та ризиком підвищення артеріального тиску (АТ), прогресії артеріальної гіпертензії (АГ), розвитку гіпертрофії ЛШ, виникнення цереброваскулярних катастроф, декомпенсації хронічної серцевої недостатності. Обмеження кухонної солі призводить до сприятливих ефектів для цілого ряду серцево-судинних захворювань. Вказівки з обмеження кухонної солі при АГ менше 5-6 г/добу, при $\mathrm{CH}$ - ще менше, внесені до всіх діючих зараз міжнародних та вітчизняних настанов. Як і інші зміни способу життя, реальне обмеження кухонної солі в раціоні дуже складно досягнуто, проте його необхідно докладно обговорювати з хворим.

Загальноприйнятою в даний час $є$ думка про те, що рівні індексу маси тіла більше 30 кг/м² пов'язані зі збільшенням серцево-судинного ризику, це необхідно донести до пацієнта. У хворих на АГ з надлишковою вагою стійке зниження маси тіла на 1 кг сприяє зниженню систолічного АТ приблизно на 2 мм рт.ст.

Безперечне значення серед заходів, спрямованих на покращення ризику СС3 є обмеження прийому алкоголю, збільшення фізичної активності, контроль емоційного статусу [2, с. 3272]. За відсутності супутніх паренхіматозних захворювань печінки вживання алкоголю 
менше 20 г/добу (представлено кількість абсолютного алкоголю, тобто чистого спирту, що можна переводити у відповідний алкогольний напій) для дорослих чоловіків та менше 10 г/добу - для дорослих невагітних жінок не асоціюється зі збільшенням серцево-судинного ризику та може навіть його зменшувати. Вживання більш значних доз алкоголю асоційоване 3 погіршенням серцево-судинного прогнозу. У осіб обох статей, вживання алкоголю призводить до виразного зростання систолічного та діастолічного АТ, причому цей вплив має чіткий дозозалежний характер. Такий ефект розглядається як один із важливих механізмів розвитку мозкових інсультів на тлі вживання великих кількостей алкоголю, за рахунок виникнення ускладненого гіпертензивного кризу.

Єдина думка експертів провідних кардіологічних асоціацій світу полягає в тому, що гіподинамія має цілий комплекс негативних біологічних ефектів і несприятливо впливає на прогноз при артеріальній гіпертензії, цукровому діабеті, хронічній IXC, серцевій недостатності. У численних роботах продемонстровано позитивні ефекти індивідуально підібраних та контрольованих фізичних навантажень на стан нервової системи, судинного русла, серця, периферичних м'язів, нейрогуморального статусу, системної запальної відповіді. Підвищення фізичної активності у стабільних кардіологічних хворих необхідно всіляко заохочувати.

Різного роду емоції, особливо - негативні, здатні чітко збільшити серцево-судинний ризик у хронічних хворих 3 серцево-судинними захворюваннями. Показано, що перегляд напруженого футбольного матчу більш ніж у 2 рази збільшує ризик розвитку гострого коронарного синдрому у чоловіків із хронічною IXC. Річниця смерті батьків пов'язана зі значним підвищенням частоти раптової смерті аритмічного генезу у осіб обох статей, але більше у чоловіків. Вважають, що перед подібними ситуаціями, якщо їх можливо передбачити, необхідно вживати профілактичних заходів, спрямованих на емоційну протекцію, а також на посилення базової терапії (подвоєння дозування статинів, підвищення дози $\beta$-адреноблокаторів).

Профілактичні та немедикаментозні підходи до лікування кардіологічних хворих займають важливе місце у розвитку серцево-судинних захворювань та потребують значної уваги з боку лікарів для їх корекції.

\section{Література:}

1. Дослідження STEPS: поширеність факторів ризику неінфекційних захворювань в Україні у 2019 році. Копенгаген, Європейське регіональне бюро ВООЗ; 2020. 66 с. Ліцензія: CC BY-NC-SA 3.0 IGO. 
2. 2021 ESC Guidelines on cardiovascular disease prevention in clinical practice European Heart Journal, Volume 42, Issue 34, 7 September 2021, Pages 3227-3337, https://doi.org/10.1093/eurheartj/ehab484

DOI https://doi.org/10.30525/978-9934-26-182-4-49

\title{
REPRODUCTIVE HEALTH IN THE CONTEXT OF PANDEMIC COVID-19
}

\author{
Nykula B. T. \\ $M D$, \\ Kyiv Clinical Hospital on Railways Transport № 2 \\ Health Centre of JSC "Ukrainian railways"
}

\section{Omelchenko E. M.}

$P h D$,

Head of the Laboratory of genetic epidemiology

State Institution «O.M. Marzelev Institute for Public Health

of the National Academy of Medical Science of Ukraine»

\section{Yelizarova O. T.}

$M D, P h D$,

Leading researcher at the Department of Public Health

State Institution «O.M. Marzelev Institute for Public Health

of the National Academy of Medical Science of Ukraine»

\section{Kyiv, Ukraine}

The onset of the COVID-19 pandemic triggered changes in both the public and private lives of millions of people and triggered negative changes in the health of the population [1]. Studying the consequences of the pandemic and the impact of its various aspects on reproductive health is one of the issues in the focus of attention of scientists.

Reproductive healthcare is a pressing issue for both the health sector and society as a whole [2]. The social significance of reproductive health is based on the increased probability of population decline and age structure change due to fertility rates decreasing in the European region, the United States, Japan, Hong Kong and other developed countries [3]. These changes might have profound economic, social, and geopolitical impacts [3]. 